\title{
The influence of TQM on export performance of SMEs: Empirical evidence from manufacturing sector in Pakistan using PLS-SEM
}

\author{
Muhammad Imran ${ }^{\text {, }}$ Siti Norasyikin binti Abdul Hamid ${ }^{\text {(* }}$ and Azelin binti Aziz
}

aPunjab Emergency Services (Rescue 1122), Lahore, Pakistan

${ }^{b}$ School of Business Management, Universiti Utara Malaysia, Sintok, Malaysia

\section{CH R O N I C L E}

Article history:

Received: November 26, 2017

Received in revised format: January 31,2018

Accepted: March 16, 2018

Available online:

March 20, 2018

Keywords:

Total quality management

Export performance

PLS-SEM analysis

SMES

Pakistan

\section{Introduction}

Exports of every country are very important for the country' economy and balance of trade. Moreover, export activity maximizes the country's foreign exchange and revenue reserves. The term of firm performance is not new in the context of strategic management. Export performance is a degree in which a firm achieves its strategic and financial objectives (Cavusgil \& Zou, 1994). In the literature of small and medium enterprises (SMEs), numerous studies have been investigated the performance of SMEs. It is investigated how the SMEs provide values for owners, customers and country as well. The SMEs export performance can be measured either to investigate the financial variable or non-financial variables (Zou \& Stan, 1998).

Several studies reported that the firm resources could be used to improve the performance of SMEs' export (Sui \& Baum, 2014). Filatotchev et al. (2009) used export orientation as antecedents of SME export performance. Similarly, in the study of SME export performance, firm size, business experience

* Corresponding author.

E-mail address: norasyikin@uum.edu.my (S.N.B.A. Hamid)

C 2018 by the authors; licensee Growing Science, Canada doi: $10.5267 / \mathrm{j} . \mathrm{msl} .2018 .3 .003$ 
and export intensity were analyzed (Majocchi et al., 2005). Lefebvre et al. (1998) investigated the research and development capabilities as antecedents of SME export performance. Moreover, Babakus et al. (2006) analyzed the perceived uncertainty and networking factors of the SMEs' export performance. According to Haahti et al. (2005) cooperative strategy and knowledge intensity could influence SMEs' export performance. Mostafa et al. (2005) stated that entrepreneurial orientation and firm management commitment were the main contributors to SMEs' export performance. In the same way Javalgi and Todd (2011) analyzed the effect of entrepreneurial orientation, management commitment and human capital on SME export performance. Furthermore, social networks (Zhou et al., 2007), trade promotion (Wilkinson \& Brouthers, 2006), marketing strategy (Filipe Lages \& Montgomery, 2004), innovation (D'Angelo, 2012), information technology (Zhang et al., 2008), government assistantship (Shamsuddoha et al., 2009) and relationship quality (Ural, 2009) were considered influential antecedent of SMEs' export performance (Gandhi et al., 2018).

Nevertheless, published studies have shown that total quality management (TQM) determines the SME export performance (Abeykoon \& de Alwis, 2016; Imran et al., 2017; Lages et al., 2009). Furthermore, Imran et al. $(2016,2017)$ stressed that SME export performance dependent on firm strategic resources as well. TQM considers a firm intangible and having a dynamic capability nature resource (El Shenawy et al., 2007) which could be beneficial for SME export performance. Furthermore, a detailed literature evaluation has revealed that very limited studies investigated the effect of TQM on SME exports success. Masakure et al. (2009) stated that there were limited studies conducted in developing countries such as Pakistan, on TQM and performance of exporting firms. However, the current study found very limited studies have been conducted regarding TQM and SME export performance relationship and especially in the context of Pakistan (Chen et al., 2016). Furthermore, Imran et al. (2017) reviewed the previous publish literature and proposed that very limited have been conducted to investigate the relationship between TQM and SME export performance. Thus, in this study, we try to investigate the relationship between TQM and SME export performance and fulfil the above mention research gaps.

\section{Literature review}

The role of small and medium business in countries' exports cannot be disregarded. To export, any country relies on small and large firm's participation. According to Dar et al. (2017) country exports can be enhanced through large participation of SMEs. Particularly, SMEs are easy to start the business, require low capital and easy to manage. These characteristics are gaining countries' intention to develop more and more small and medium business, which are beneficial for country's exports (Rehman, 2016). China increased the export volume through the large participation of small and medium business and has become the biggest exporter in the world (Muller et al., 2015). The participation of Pakistan's SMEs in exports is very low which is $30 \%$ in GDP and $25 \%$ in country's exports (Yoshino \& Wignaraja, 2015). However, this contribution is very low compared with a regional competitor such as India (37.5\%) and behind from China's (60\%) and Japan's (55\%). Declining in exports causing trade deficit and failure to fulfil trade quotas and it is now becoming a burden on the economy (Hamza, 2016; Munir, 2016).

Pakistan SMEs have a potential and opportunities to improve their performance (Nation, 2016). Moreover, Government of Pakistan has been taking priority steps for the betterment of SMEs, they believe SMEs have good potential to achieve the country's highest export target mission of 2025, it estimated around 30 billion USD exports per year (LCCI, 2017). Currently, Pakistan's total export is FY 2016 \$ 17.32 billion which is very low compared with previous years such as in FY 2014 exports which was recorded as 21.21 \$ billions and in FY 2015 it dropped to \$ 19.55 billion, and further decreased in FY 2016, which was the lowest in Pakistan history of modern era (PBS, 2016). However, there are many factors influencing the SME export performance (Chen et al., 2016). The previous researchers found the absence of total quality management (Haroon \& Shariff, 2016; Latif et al., 2014; Masakure et al., 2009; Saeed \& Hasnu, 2011) in the manufacturing sector of Pakistan. Moreover, they suggested that owners of SMEs and Government of Pakistan should consider these factors for SME to increase the 
export performance. About $85 \%$ of the exports of Pakistan are relying on the manufacturing sector (Khan \& Khalique, 2014).

Kanji (1990) stated that TQM is a process to improve the firm's products, processes, and services to achieve the customer satisfaction at low-cost (Kanji, 1990). The operationalization of TQM is not yet developed, subsequently, researchers operationalized the TQM on the basis of TQM practices, Malcolm Baldrige National Quality Award (MBNQA) and European Foundation for Quality Management (EFQM) (Jafari, 2013). Moreover, the most famous model which got more intention is a European Foundation for Quality Management (EFQM) and is more applicable in the evaluation of the firm function (Shafiq, 2012; Muhammad Shafiq et al., 2017). However, some of the researchers found a positive link between TQM and firm export performance and further suggested that TQM could be an influential resource for SME export performance (Abeykoon \& de Alwis, 2016; Lages et al., 2009; Masakure et al., 2009).

Hence the study proposes the following hypothesis:

$\mathbf{H}_{1}$ : There is a relationship between total quality management and SME export performance in the manufacturing sector of Pakistan.

\subsection{Framework}

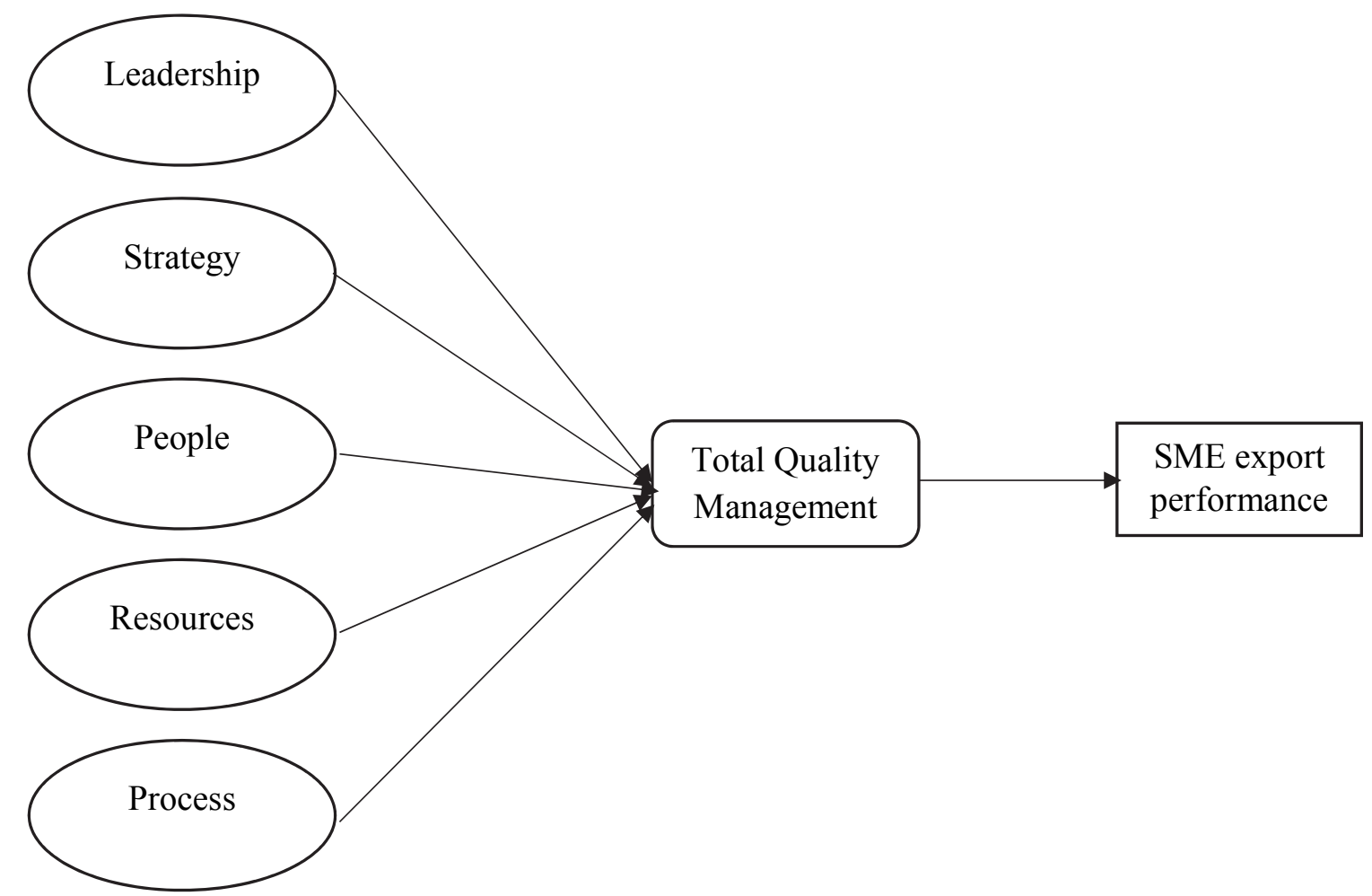

Fig. 1. Study framework

The research framework is underpinning the resource-based view theory (Akio, 2005). The primary goal of the present research is to examine the effect of the interaction between TQM and the firm performance such as the export performance of the firm. A thorough literature review discloses that the variables chosen in this study have been underpinned by the RBV. Specifically, TQM is considered as one of the primary sources of competitive advantage (Belén Escrig-Tena, 2004; El Shenawy et al., 2007). Furthermore, over the years RBV has become a critical driver of export performance (Eisenhardt $\&$ Martin, 2000; İpek, 2017). Export performance can be explained by resource-based view (Cadogan 
et al., 2009; Chen et al., 2016; İpek, 2017; Lages, 2000). More importantly, the establishment of competitive advantage needs to be dynamic for the survival and growth of the firm in an ever-changing and ever-competitive market environment (Teece et al., 1997). However, the theory is limited to the firm level and does not address critical, external factors such as market dynamism. Therefore, this research is also anchored by the theory of Dynamic Capabilities (DC) that extends RBV to include dynamic external factors in addressing the integration and reconfiguration of both internal and external competencies. In the RBV, resources and capabilities are heterogeneous and 'sticky' which means difficult to change in the short term (Galunic \& Eisenhardt, 2001) and difficult to sustain their values. Firms may achieve new forms of competitive advantage through dynamic capabilities (Teece et al., 1997). Accordingly, the term 'dynamic' is related to the rate of change. While the term 'capabilities' refers to the strategic management role in appropriately adapting, integrating and reconfiguring internal and external skills, resources and functional competencies to address the rapidly changing environment (Winter, 2003). Firms need to reconfigure the variety of capabilities they possess in facing the challenges of the changing business environment (Teece, 2007). The characteristics of DC include higher order, futureoriented, resources and capabilities changing, persistent, embedded, behavioral implications, strategy making - align with several highly researched strategic orientations in the marketing and management literature including TQM (Haroon \& Shariff, 2016).

\section{Research methodology}

\subsection{Population, sample size, and respondent}

This study was conducted in the context of manufacturing SMEs of Pakistan. Registered companies on Pakistani exporter directories were taken as the study population. The companies included in this study were meeting basic criteria such as "business should meet the definition of SMEs and involve in manufacturing and export operations". The same criteria were used by Ibeh (2004) and Okpara and Kabongo (2009) in different contexts. According to recommended criteria, 6994 exporters from top eight manufacturing export-orientated sub-sectors such as textiles (2072), surgical (1100), Sports goods industry (1000), Leather industry (905), Jam and Jewelry (448), Cutlery (218), Automobile parts (332), Pharmaceutical (600), Fan industry (169) and Furniture industry (150) were identified.

The study, used the Krejcie and Morgan (1970) table to determine the sample size. By referring the Krejcie and Morgan (1970) sample size table, three hundred sixty-four (364) SMEs were selected as a sample size for the study. Moreover, Beh and Shafique (2016) stated that manufacturing SMEs of Pakistani response rate was $46 \%$. The sample size of the study increased 54\% for maximum response rate and try to control the non-response error (Salkind, 2012; Saunders et al., 2009). Moreover, according to Sekaran and Bougie (2016) for the maximum response rate, we sent a reminder phone calls and emails to respondents after the questionnaires had been delivered. The stratified sampling technique was also used. In this sampling method, the number of sampling units drawn from each stratum was proportionate to the population size of the stratum (Eriksson \& Kovalainen, 2015). The study sample was divided into ten (10) strata such as textiles/apparel (167), surgical (88), sports goods (80), leather/footwear (73), pharmaceutical (48), Jam/ Jewelry (36), Auto Parts (28), cutlery (18). Electrical goods (14) and Furniture (12). The firm-level was taken as a unit of analysis and taken the response from firm owners/export managers (Calantone et al., 2004; Cavusgil \& Zou, 1994). A total of 572 questionnaires was distributed to furniture industry firms, only 364 firms participated in the survey with a response rate of $64.54 \%$. This response was acceptable (Beh \& Shafique, 2016; Hassan et al., 2017; Hussain et al., 2015; Khalique et al., 2015). 


\subsection{Measures of Variables}

Measures of the variable were adapted from the past studies. The TQM in this study contains five dimensions including leadership, strategy, people, resources, and process contained with numbers of 6, 6, 6,5 and 7, respectively (Muhammad Shafiq et al., 2017). In addition, the modified version of Zou et al. (1998) export performance (EXPERF) scale with 9 items (Shoham et al., 2008) was adapted. A seven-point Likert scale was used to ensure the high statistical variability among responses, which ranging from 1(Strongly disagree), 2 (Disagree), 3 (Somewhat disagree), 4 (Neutral), 5 (Somewhat agree), 6 (Agree), 7 (Strongly agree) (Choi \& Eboch, 1998). The details of the construct dimensions with items can be seen in Table 1.

\section{Table 1}

Scale of SME export performance and total quality management

\begin{tabular}{|c|c|}
\hline Items & SME export performance \\
\hline \multirow[t]{3}{*}{ Financial } & Our firm export has been very profitable. \\
\hline & Our firm export has generated a high volume of sales. \\
\hline & Our firm export has achieved rapid growth. \\
\hline \multirow[t]{3}{*}{ Strategic } & Our firm export has improved our global competitiveness. \\
\hline & Our firm export has strengthened our strategic position. \\
\hline & Our firm export has significantly increased our global market share. \\
\hline \multirow[t]{3}{*}{ Satisfaction } & The export performance of our firm has been satisfactory. \\
\hline & Our firm export has been successful. \\
\hline & Our firm export has fully met our expectation. \\
\hline Items & Total Quality Management \\
\hline \multirow[t]{6}{*}{ Leadership } & Managers of our company view the cost as more important in comparison to the quality of products. \\
\hline & Managers of our company present themselves as role models for the employees. \\
\hline & Managers of our company ensure that employees are aware of the company's long-term plans. \\
\hline & Managers of our company do not want to give authority to employees for them to take decisions about their jobs. \\
\hline & Managers of our company continuously acquire and update their knowledge that is valuable for the organization. \\
\hline & Managers of our company encourage and participate in continuous improvement initiatives. \\
\hline \multirow[t]{6}{*}{ Strategy } & $\begin{array}{l}\text { In our company, the views of customers (the people/companies who buy or want to buy your company's products) are consid- } \\
\text { ered important while designing new products. }\end{array}$ \\
\hline & In our company, the views of suppliers are considered while shaping the company's objectives. \\
\hline & In our company, the performance of competitors and best-in-class companies is assessed and analyzed. \\
\hline & $\begin{array}{l}\text { In our company, systematic measurement of losses (such as production losses, the losses due to rejection of finished products, } \\
\text { etc.) is carried out. }\end{array}$ \\
\hline & In our company, information systems are in place to capture information about customers and markets. \\
\hline & $\begin{array}{l}\text { In our company, periodically (e.g. after every three months, six months, or one year), organizational performance is evaluated } \\
\text { against the set objectives and targets. }\end{array}$ \\
\hline \multirow[t]{6}{*}{ People } & $\begin{array}{l}\text { In our company, formal processes are used regularly (attitude surveys, employees' briefing, etc.) to find out employees' opin- } \\
\text { ions and views. }\end{array}$ \\
\hline & In our company, specific quality training is offered to employees. \\
\hline & In our company, employees are encouraged to update their knowledge and skills. \\
\hline & In our company, teamwork is a common practice within the organization. \\
\hline & In our company, employees have easy access to the relevant information. \\
\hline & In our company, encourage the employee's opinions, suggestions about any of the activities of the organization. \\
\hline \multirow[t]{5}{*}{ Resources } & In our company, suppliers are encouraged to develop long-term partnerships with the organization. \\
\hline & In our company does not give preference to quality over cost while making purchase agreements with suppliers. \\
\hline & In our company, performance of the suppliers is evaluated periodically. \\
\hline & In our company, updated information and resources are provided to all employees to perform their jobs. \\
\hline & In our company tries to reduce the harmful effect of its activities on the environment. (Partnership and resources) \\
\hline \multirow[t]{7}{*}{ Process } & In our company, proper procedures are established to perform different jobs. \\
\hline & $\begin{array}{l}\text { In our company, employees are aware of the parameters (temperature, pressure, etc.) of different processes, which are needed } \\
\text { to be controlled for effective operation. }\end{array}$ \\
\hline & In our company, performance of production processes is monitored. \\
\hline & In our company, development and innovation of production processes are emphasized. \\
\hline & $\begin{array}{l}\text { In our company, the research and development }(\mathrm{R} \& \mathrm{D}) \text { department is continuously working on the development and improve- } \\
\text { ment of the products. }\end{array}$ \\
\hline & In our company, production processes are capable of producing products according to design specifications. \\
\hline & In our company, proper systems are in place to deal with customer complaints. \\
\hline
\end{tabular}




\subsection{Data Analysis and Results}

SmartPLS3 is used to evaluate the SEM analysis. In the current study we have adopted the second-order reflective-formative hierarchical model, type II, proposed by Becker et al. (2012). Moreover, a two-stage approach was used to incorporate TQM dimensions as exogenous variables and SME export performance as an endogenous variable in the research model (Hair Jr et al., 2016). In this current study, TQM is a higher order formative constructs as formed by first-order reflective dimensions such are leadership, strategy, people, process and resources. The endogenous variable (SME export performance) of the study was treated as the first order reflective construct. Furthermore, the decision to construct nature regarding reflective or formative is not clear yet (Hair Jr et al., 2016). However Becker et al. (2012) suggested that the best combination of the second-order constructs is a reflective-formative model. With respect to measurement model, Ringle et al. (2012) suggested that researcher should implement the reflective-formative, formative-formative and formative-reflective type models in their studies. On the other hand Zhang et al. (2008) suggested that before further analysis of PLS-SEM, researchers distinguished the reflective and formative measures to use the PLS-SEM confirmatory tetrad analysis. Therefore, this study conducted PLS-SEM confirmatory analysis for TQM and the results of the test confirm the operationalization of the construct empirically and the results found that TQM was a reflective-formative second construct. In the study, Para-González et al. (2016) TQM was operationalized as a reflective-formative construct. Hence, we followed the Teixeira et al. (2016) study to run the two-stage approach. In the first step, we have validated the reflective type firstorder constructs in one model and reported the indicator loadings, AVE, composite reliability and discriminant validity (Becker et al., 2012). In the second step, we took the latent variable score from the first model and made a two-stage model. For the formative measurement model confirmation to run the bootstrapping on 5000 resampling, we have reported the weights and the maximum variance inflation factor (VIF) to validate the measurement model for formative constructs (Hair Jr et al., 2016).

\subsection{Measurement Model}

In measurement model, internal consistency, convergent validity and discriminant validity of constructs were investigated. Internal consistency of constructs was based on Cronbach Alpha, composite and rho values. George and Mallery (2003) provided the rule of deciding the value, "alpha; " $\alpha>0.9$ - Excellent, $\alpha<0.8$ - Good, $\alpha<0.7$ - Acceptable". Composite reliability should be accepted on the value of 0.70 and higher for better internal consistency of the data (Fornell \& Larcker, 1981). The reliability measure rho_A is an estimate of the squared correlation of the PLS construct score with true construct score and reliability coefficient value not less than .70. Thus, in this study we have achieved all threshold values of Cronbach alpha, composite reliability and rha_A.

According to Hair et al. (2010), the convergent validity is attained when the factor loadings of all the items are higher than the values of 0.4, 0.5, 0.6, 0.7 and average variance extracted (AVE) of constructs are higher than 0.5 value (Fornell \& Larcker, 1981). Hence, we achieved threshold value of .04 for all factors loading and AVE more than 0.5 value. In terms of discriminant validity criterion, cross-loadings and Heterotrait-Monotrait ratio (HTMT) were analysed to determine the model external consistency. According to Fornell and Larcker (1981), the AVE of the latent variable should be higher than the squared correlations between the latent variables. The HTMT was developed to address insensitivity of the Fornell and Larcker (1981) and cross loading criterion, HTMT values close to one indicate a lack of discriminant validity (Henseler et al., 2015). The HTMT index is the average of the heterotraitheteromethod correlations relative to the average monotrait-heteromethod correlations. All values of HTMT index should be less than 0.90, thereby confirming discriminant validity (Henseler et al., 2015). Therefore, according to above-mentioned criteria we achieved discriminant validity of all constructs, we can see the results of Fornell and Larcker in Table 2, cross-loadings of the construct in the Table 3 and HTMT values in a Table 4. 
Fig. 2. PLS-SEM Algorithm (measurement model) AVE and Factors loading of items ( $1^{\text {st }}$ order)

\section{Table 2}

Finding of the measurement model (First Order, Reflective)

\begin{tabular}{|c|c|c|c|c|c|c|}
\hline Constructs & Items & Loadings & Alpha & Rho_A & CR & AVE \\
\hline \multirow[t]{6}{*}{ Leadership } & Lea1 & 0.634 & 0.82 & 0.83 & 0.87 & 0.520 \\
\hline & Lea2 & 0.801 & & & & \\
\hline & Lea3 & 0.776 & & & & \\
\hline & Lea4 & 0.653 & & & & \\
\hline & Lea5 & 0.733 & & & & \\
\hline & Lea6 & 0.750 & & & & \\
\hline \multirow[t]{6}{*}{ Strategy } & Str1 & 0.656 & 0.82 & 0.91 & 0.86 & 0.511 \\
\hline & Str2 & 0.584 & & & & \\
\hline & Str3 & 0.731 & & & & \\
\hline & Str4 & 0.642 & & & & \\
\hline & Str5 & 0.793 & & & & \\
\hline & Str6 & 0.849 & & & & \\
\hline \multirow[t]{5}{*}{ People } & Peo2 & 0.631 & 0.79 & 0.94 & 0.84 & 0.512 \\
\hline & Peo3 & 0.649 & & & & \\
\hline & Peo4 & 0.750 & & & & \\
\hline & Peo5 & 0.808 & & & & \\
\hline & Peo6 & 0.726 & & & & \\
\hline \multirow[t]{3}{*}{ Resources } & Res1 & 0.848 & 0.76 & 0.78 & 0.86 & 0.673 \\
\hline & Res3 & 0.849 & & & & \\
\hline & Res4 & 0.762 & & & & \\
\hline \multirow[t]{7}{*}{ Process } & Pro1 & 0.699 & 0.873 & 0.884 & 0.901 & 0.546 \\
\hline & Pro2 & 0.661 & & & & \\
\hline & Pro3 & 0.765 & & & & \\
\hline & Pro4 & 0.823 & & & & \\
\hline & Pro5 & 0.786 & & & & \\
\hline & Pro6 & 0.769 & & & & \\
\hline & Pro7 & 0.653 & & & & \\
\hline \multirow[t]{9}{*}{ SME export performance } & EP1 & 0.815 & 0.92 & 0.93 & 0.93 & 0.603 \\
\hline & EP2 & 0.845 & & & & \\
\hline & EP3 & 0.870 & & & & \\
\hline & EP4 & 0.870 & & & & \\
\hline & EP5 & 0.775 & & & & \\
\hline & EP6 & 0.817 & & & & \\
\hline & EP7 & 0.600 & & & & \\
\hline & EP8 & 0.647 & & & & \\
\hline & EP9 & 0.700 & & & & \\
\hline
\end{tabular}

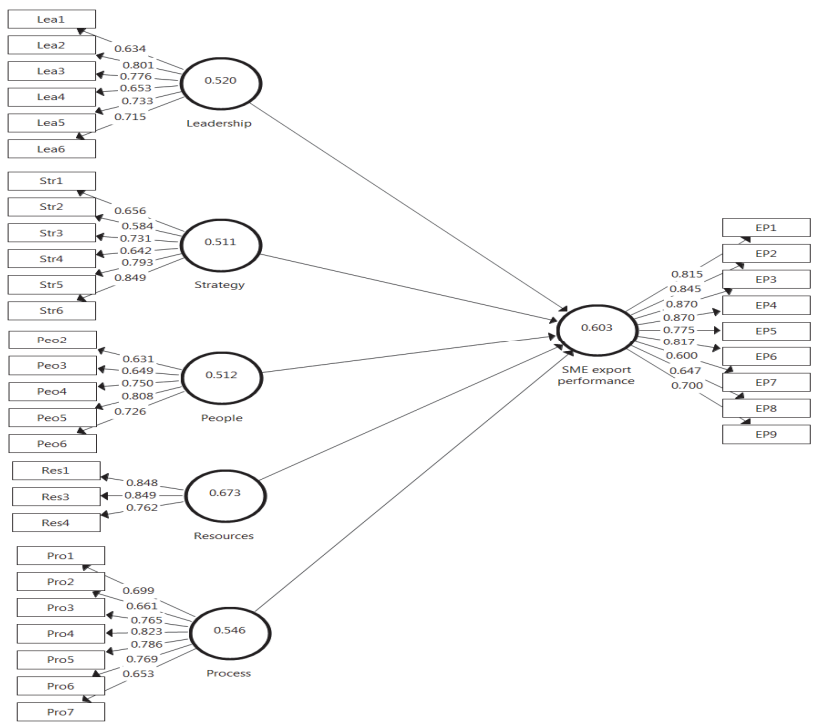


Table 3

Fornell-Larcker Criterion

\begin{tabular}{|c|c|c|c|c|c|c|}
\hline & Leadership & People & Process & Resources & SME export performance & Strategy \\
\hline Leadership & 0.72 & & & & & \\
\hline People & 0.43 & 0.72 & & & & \\
\hline Process & 0.42 & 0.55 & 0.74 & & & \\
\hline Resources & 0.28 & 0.16 & 0.09 & 0.82 & & \\
\hline SME export performance & 0.48 & 0.34 & 0.38 & 0.13 & 0.78 & \\
\hline Strategy & 0.42 & 0.53 & 0.46 & 0.34 & 0.22 & 0.71 \\
\hline
\end{tabular}

Table 4

Cross loadings

\begin{tabular}{|c|c|c|c|c|c|c|}
\hline & SME export performance & People & Leadership & Process & Resources & Strategy \\
\hline EP1 & 0.82 & 0.28 & 0.38 & 0.33 & 0.01 & 0.1 \\
\hline EP2 & 0.85 & 0.28 & 0.4 & 0.32 & 0.03 & 0.17 \\
\hline EP3 & 0.87 & 0.3 & 0.52 & 0.34 & 0.11 & 0.17 \\
\hline EP4 & 0.87 & 0.28 & 0.41 & 0.35 & 0.09 & 0.14 \\
\hline EP5 & 0.78 & 0.22 & 0.36 & 0.23 & 0.12 & 0.16 \\
\hline EP6 & 0.82 & 0.28 & 0.35 & 0.34 & 0.07 & 0.15 \\
\hline EP7 & 0.60 & 0.22 & 0.32 & 0.24 & 0.17 & 0.21 \\
\hline EP8 & 0.65 & 0.25 & 0.3 & 0.24 & 0.21 & 0.3 \\
\hline EP9 & 0.70 & 0.27 & 0.3 & 0.26 & 0.19 & 0.2 \\
\hline Lea1 & 0.14 & 0.63 & 0.27 & 0.29 & 0.2 & 0.49 \\
\hline Lea2 & 0.13 & 0.65 & 0.26 & 0.37 & 0.23 & 0.55 \\
\hline Lea3 & 0.15 & 0.75 & 0.24 & 0.37 & 0.16 & 0.48 \\
\hline Lea4 & 0.4 & 0.81 & 0.37 & 0.49 & 0.02 & 0.25 \\
\hline Lea5 & 0.2 & 0.73 & 0.34 & 0.36 & 0.16 & 0.44 \\
\hline Lea6 & 0.19 & 0.2 & 0.63 & 0.14 & 0.18 & 0.2 \\
\hline Peo2 & 0.41 & 0.35 & 0.80 & 0.38 & 0.24 & 0.33 \\
\hline Peo3 & 0.31 & 0.38 & 0.78 & 0.34 & 0.24 & 0.39 \\
\hline Peo4 & 0.35 & 0.25 & 0.65 & 0.24 & 0.03 & 0.18 \\
\hline Peo5 & 0.39 & 0.3 & 0.73 & 0.32 & 0.18 & 0.28 \\
\hline Peo6 & 0.37 & 0.33 & 0.71 & 0.31 & 0.33 & 0.39 \\
\hline Pro1 & 0.27 & 0.43 & 0.34 & 0.7 & 0.06 & 0.34 \\
\hline Pro2 & 0.19 & 0.39 & 0.27 & 0.66 & 0.04 & 0.37 \\
\hline Pro3 & 0.3 & 0.45 & 0.31 & 0.77 & 0.06 & 0.33 \\
\hline Pro4 & 0.29 & 0.45 & 0.31 & 0.82 & 0.06 & 0.39 \\
\hline Pro5 & 0.34 & 0.39 & 0.33 & 0.79 & 0.06 & 0.34 \\
\hline Pro6 & 0.34 & 0.36 & 0.35 & 0.77 & 0.09 & 0.32 \\
\hline Pro 7 & 0.21 & 0.38 & 0.24 & 0.65 & 0.11 & 0.32 \\
\hline Res1 & 0.13 & 0.18 & 0.26 & 0.04 & 0.85 & 0.26 \\
\hline Res3 & 0.1 & 0.02 & 0.13 & 0 & 0.85 & 0.21 \\
\hline Res4 & 0.09 & 0.19 & 0.28 & 0.2 & 0.76 & 0.37 \\
\hline Str1 & 0.09 & 0.34 & 0.29 & 0.35 & 0.27 & 0.66 \\
\hline Str2 & 0.11 & 0.27 & 0.2 & 0.22 & 0.28 & 0.58 \\
\hline Str3 & 0.1 & 0.38 & 0.24 & 0.32 & 0.21 & 0.73 \\
\hline Str4 & 0.1 & 0.35 & 0.25 & 0.24 & 0.26 & 0.64 \\
\hline Str5 & 0.19 & 0.46 & 0.34 & 0.39 & 0.24 & 0.79 \\
\hline Str6 & 0.25 & 0.45 & 0.39 & 0.4 & 0.25 & 0.85 \\
\hline
\end{tabular}

Note: EP (SME export performance), Peo (People), Lea (Leadership), Pro (Process), Res (Resources), Str (Strategy)

\section{Table 5}

Heterotrait-Monotrait Ratio (HTMT)

\begin{tabular}{lcccccc}
\hline & Leadership & People & Process & Resources & SME export performance & Strategy \\
\hline Leadership & & & & & & \\
People & 0.49 & & & & & \\
Process & 0.47 & 0.62 & & & & \\
Resources & 0.37 & 0.3 & 0.14 & & & \\
SME export performance & 0.53 & 0.33 & 0.42 & 0.18 & & 0 \\
Strategy & 0.48 & 0.73 & 0.54 & 0.45 & 0.24 & \\
\hline
\end{tabular}




\subsubsection{Measurement model for formative constructs}

We have checked the significance of the weights with a resampling procedure on bootstrapping with 5000 resamples. The study found one item nonsignificant in outer weights $(p<.05)$ analysis, such as QMR, but was retained due to high significant $(\mathrm{p}<.05)$ of outer loadings (Hair Jr et al., 2016). This decision was not only made for the protection of the items validity of the formative constructs, but also the fact that when measuring a construct with many formative indicators, it becomes more likely that one or more indicators would have low or nonsignificant outer weights (Hair Jr et al., 2016). Second criterion is to check the constructs multicollinearity issues. According to Hair Jr et al. (2016) VIF value of five (5) and higher indicates the potential collinearity issue. Thus, we found that there is no issue of multicollinearity. The results of formative construct are presented in Fig. 3 and Table 6.

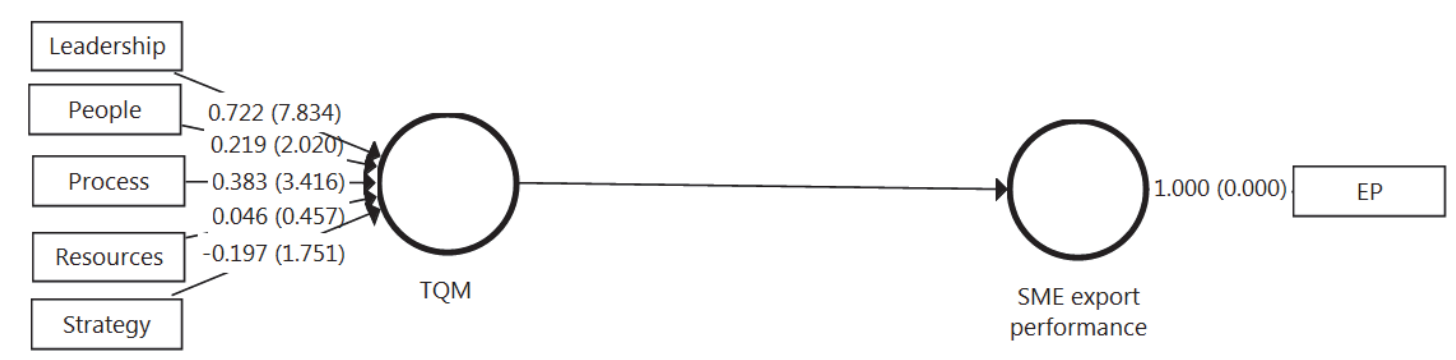

Fig. 3. Measurement model $-2^{\text {nd }}$ order (formative) two-stage approach (outer weights / T-value)

Table 6

Findings of Measurement Model for Formative constructs

\begin{tabular}{|c|c|c|c|c|c|c|}
\hline Constructs & Indicator & Outer loading & $\mathrm{OL}$ & Outer & OW & VIF \\
\hline \multirow{5}{*}{$\begin{array}{l}\text { Total Quality } \\
\text { Management }\end{array}$} & Leadership & 0.91 & $21.52 * * *$ & 0.72 & $7.83 * * *$ & 1.4 \\
\hline & People & 0.64 & $7.98 * * *$ & 0.22 & $2.02 * *$ & 1.72 \\
\hline & Process & 0.72 & $9.15 * * *$ & 0.38 & $3.42 * * *$ & 1.59 \\
\hline & Resources & 0.25 & $2.24 * * *$ & 0.05 & $0.46(\mathrm{~ns})$ & 1.18 \\
\hline & Strategy & 0.41 & $4.02 * * *$ & -0.2 & $1.75^{*}$ & 1.66 \\
\hline
\end{tabular}

\subsection{Structural Model Assessment}

After the assessment of the measurement model, the structural model was assessed to draw the conclusion. We have evaluated four things in structural model to use the two-stage approach model, such as coefficient of determination $\left(\mathrm{R}^{2}\right)$, effect size $\left(\mathrm{F}^{2}\right)$, path coefficient.

\subsubsection{The coefficient of determination $\left(R^{2}\right)$ and effect size $\left(F^{2}\right)$}

$R^{2}$ is a major part of a structural model evaluation. $R^{2}$ value of $0.25,0.50$, and 0.70 are referred to as a weak, moderate, and strong coefficient of determination, respectively (Hair et al., 2014). In our case, the total quality management explains only $29 \%$ of the SME export performance in the manufacturing sector of Pakistan.

Furthermore, we have examined the effect size ( $f 2)$. According to Hair et al. (2014), the effect of size is explained as the exogenous variable contribution into $R^{2}$ values of the endogenous variable. Moreover, the effect size ( 2 ) was considered as small (0.02), medium (0.15) and large (0.35) (Cohen et al., 2013). In this current study, we have found TQM-EP (0.40) large. The results of $R^{2}$ and $F^{2}$ can be seen in Fig. 4. Moreover, a graphical representation of $\mathrm{F}^{2}$ are shown in Fig. 5 as well. 


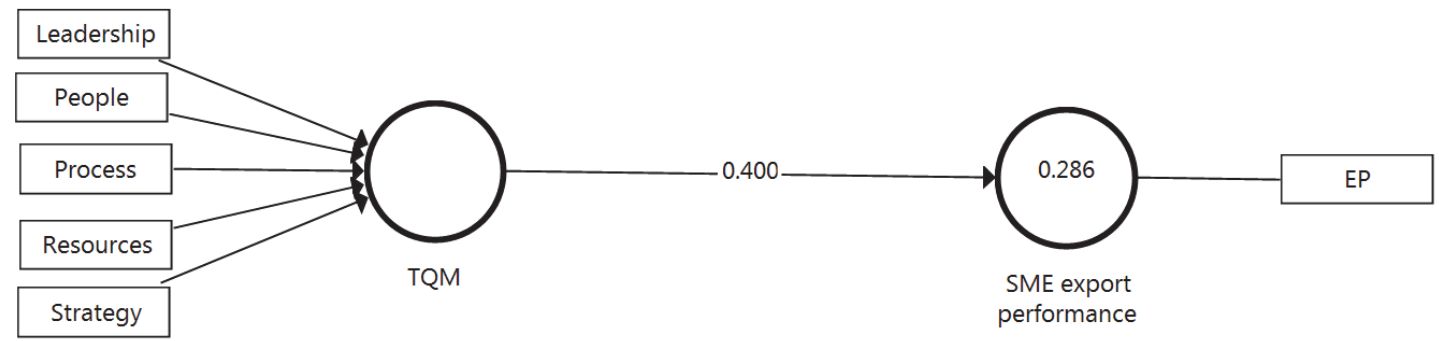

Fig. 4. Values of R2 and $\mathrm{f} 2$

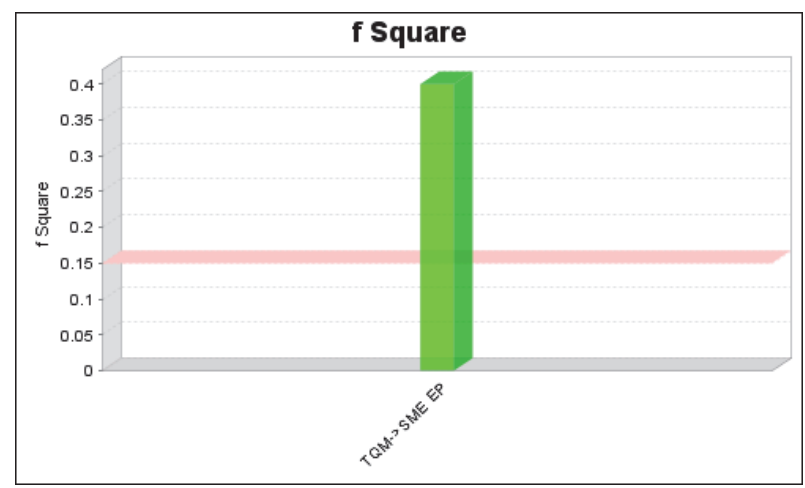

Fig. 5. $F^{2}$ graphical representation

\subsubsection{Path Coefficient}

In smart-PLS, structure model gave an inner-modelling analysis of the direct association between the variables of the study including t-values and path coefficients. As claimed by Henseler et al. (2009), the path coefficients are like regression analysis and standardized beta coefficient. Wherever, the beta values are the coefficients of regression and t-values are analyzed to decide the significance level of the constructs. However, based on the rule of thumb revealed by Hair et al. (2014), which explains that Bootstrapping method was performed (with 5000 sampling iterations for 364 cases/observations) to determine the beta-values of the coefficient of the regression and t-values which must be greater than 1.96 to consider the resulted value, significantly. The main objective of the current study is to weight on the model evaluation by analyzing the relationships between constructs.

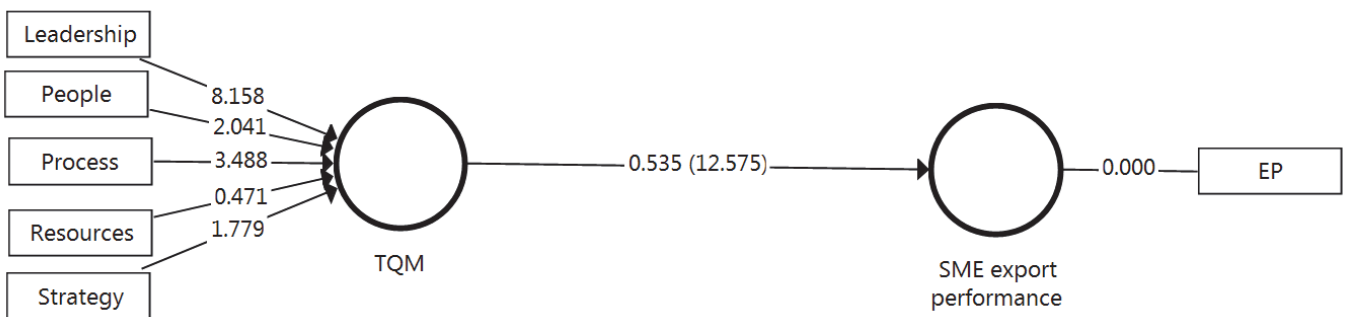

Fig. 6. PLS-SEM Bootstrapping (structural model) Beta and t-values

Table 7

Findings of structural model (path coefficient)

\begin{tabular}{lccccc}
\hline & Beta & Standard Deviation (SD) & T Statistics & P Values & Decision \\
\hline TQM - SME export performance & 0.54 & 0.04 & 12.57 & 0.000 & Supported \\
\hline Note: $p<0.1^{*} p<0.05^{* *} p<0.01^{* * *}$ (Two Tail) & & & & &
\end{tabular}


We have found a positive relationship between TQM and SME export performance. Moreover, Fig 6 demonstrates the direct effect of the independent variable (TQM) on the dependent variable (SME export performance). Table 7 shows that all values of direct relationship which are above the threshold values such as above then 1.96 .

\section{Discussion and conclusion}

First, the results of this study have shown that total quality management explained $28.6 \%$ of the SME export performance variance. The current study has found a strong and positive relationship between TQM $(\beta=0.54$; $t$-value $=12.57)$ and SME export performance. The result is consistent with previous studies (Abeykoon \& de Alwis, 2016; Gudergan et al., 2008; Lages et al., 2009). TQM has the ability to maintain all business functions according to target customers, which is the key to achieve sustainable competitive advantage (El Shenawy et al., 2007). This study has further confirmed and validated the research conclusion of statistically significant relationship between TQM and export performance. In general, the result provides further support for the assertion of the RBV and theory confirming the positive influence of this VRIN resource on the export performance of the furniture industry SMEs. Therefore, TQM with dimensions of leadership, strategy, people, resources and process which are directly involved in whole business operations interrelate with all components of TQM and these elements should be considered for decision taking. Moreover, the results have suggested that SMEs of Pakistan need to have TQM abilities, as it can provide them more business reputation regarding product and service quality and alternatively will get maximum success in international market which leads to higher export performance. Furthermore, this study has contributed to the literature and to the practice of companies by helping the firms understand how the process of TQM currently produces a better export performance.

Future recommendations: current study's framework could be validated in different country context and different sectors such as service industry. In addition, this is a cross-sectional study and the study should be validated through longitudinal methodology. Lastly, the third variable can be used between the relationship of TQM and SME export performance as mediation or moderation for more explanation of the relationship between TQM and SME export performance.

\section{References}

Abeykoon, M., \& de Alwis, A. (2016). The Impact of Total Quality Management Practices on Export Performance of Apparel Exporters of Sri Lanka. Kelaniya Journal of Human Resource Management, 10(1).

Akio, T. (2005). The Critical Assessment of the Resource-Based View of Strategic Management. Ritsumeikan International Affairs, 3, 125-150.

Babakus, E., Yavas, U., \& Haahti, A. (2006). Perceived uncertainty, networking and export performance: A study of Nordic SMEs. European Business Review, 18(1), 4-13.

Becker, J.-M., Klein, K., \& Wetzels, M. (2012). Hierarchical latent variable models in PLS-SEM: guidelines for using reflective-formative type models. Long Range Planning, 45(5), 359-394.

Beh, L.-S., \& Shafique, I. (2016). Does leadership matter in innovation and new business venturing? testing the mediating effect of absorptive capacity. International Journal of Innovation, Management and Technology, 7(5), 206.

Belén Escrig-Tena, A. (2004). TQM as a competitive factor: A theoretical and empirical analysis. International Journal of Quality \& Reliability Management, 21(6), 612-637.

Cadogan, J. W., Kuivalainen, O., \& Sundqvist, S. (2009). Export market-oriented behavior and export performance: quadratic and moderating effects under differing degrees of market dynamism and internationalization. Journal of international Marketing, 17(4), 71-89.

Calantone, R. J., Tamer Cavusgil, S., Schmidt, J. B., \& Shin, G. C. (2004). Internationalization and the dynamics of product adaptation-An empirical investigation. Journal of Product Innovation Management, 21(3), 185198.

Cavusgil, S. T., \& Zou, S. (1994). Marketing strategy-performance relationship: an investigation of the empirical link in export market ventures. The Journal of Marketing, 1-21. 
Chen, Sousa, C., \& He, X. (2016). The determinants of export performance: a review of the literature 20062014. International Marketing Review, 33(5), 626-670.

Choi, T. Y., \& Eboch, K. (1998). The TQM paradox: relations among TQM practices, plant performance, and customer satisfaction. Journal of Operations management, 17(1), 59-75.

Cohen, J., Cohen, P., West, S. G., \& Aiken, L. S. (2013). Applied multiple regression/correlation analysis for the behavioral sciences: Routledge.

D'Angelo, A. (2012). Innovation and export performance: a study of Italian high-tech SMEs. Journal of Management \& Governance, 16(3), 393-423.

Dar, M. S., Ahmed, S., \& Raziq, A. (2017). Small and medium-sie enterprises in Pakistan: Definition and critical issues. Pakistan Business Review, 19(1), 46-70.

Eisenhardt, K. M., \& Martin, J. A. (2000). Dynamic capabilities: what are they? Strategic Management Journal, 21(10-11), 1105-1121.

El Shenawy, E., Baker, T., \& Lemak, D. J. (2007). A meta-analysis of the effect of TQM on competitive advantage. International Journal of Quality \& Reliability Management, 24(5), 442-471.

Eriksson, P., \& Kovalainen, A. (2015). Qualitative Methods in Business Research: A Practical Guide to Social Research: Sage.

Filatotchev, I., Liu, X., Buck, T., \& Wright, M. (2009). The export orientation and export performance of hightechnology SMEs in emerging markets: The effects of knowledge transfer by returnee entrepreneurs. Journal of International Business Studies, 40(6), 1005-1021.

Filipe Lages, L., \& Montgomery, D. B. (2004). Export performance as an antecedent of export commitment and marketing strategy adaptation: Evidence from small and medium-sized exporters. European Journal of Marketing, 38(9/10), 1186-1214.

Fornell, C., \& Larcker, D. F. (1981). Evaluating structural equation models with unobservable variables and measurement error. Journal of Marketing Research, 39-50.

Galunic, D. C., \& Eisenhardt, K. M. (2001). Architectural innovation and modular corporate forms. Academy of Management Journal, 44(6), 1229-1249.

Gandhi, S., Sachdeva, A \& Gupta, A. (2018). Distributor service quality in Indian SMEs: A bi-directional customer perspective.Uncertain Supply Chain Management, 6(4), 335-356.

George, D., \& Mallery, M. (2003). Using SPSS for Windows step by step: a simple guide and reference.

Gudergan, S. P., Ringle, C. M., Wende, S., \& Will, A. (2008). Confirmatory tetrad analysis in PLS path modeling. Journal of Business Research, 61(12), 1238-1249.

Haahti, A., Madupu, V., Yavas, U., \& Babakus, E. (2005). Cooperative strategy, knowledge intensity and export performance of small and medium sized enterprises. Journal of world business, 40(2), 124-138.

Hair, J. F., Anderson, R. E., Babin, B. J., \& Black, W. C. (2010). Multivariate data analysis: A global perspective (Vol. 7): Pearson Upper Saddle River, NJ.

Hair, J. F., Hult, G. T. M., Ringle, C. M., \& Sarstedt, M. (2014). A Primer on Partial Least Squares Structural Equation Modeling (PLS-SEM). Los Angeles, CA: SAGE.

Hair Jr, J. F., Hult, G. T. M., Ringle, C., \& Sarstedt, M. (2016). A primer on partial least squares structural equation modeling (PLS-SEM) (2nd ed.). Thousand Oaks, CA: SAGE.

Hamza, A. (2016). Pakistan's trade deficit widens to 35-year high in FY16. Daily Times. Retrieved from http://dailytimes.com.pk/business/16-Jul-16/pakistans-trade-deficit-widens-to-35-year-high-in-fy16

Haroon, U., \& Shariff, M. N. M. (2016). The interplay of innovation, TQM practices and SMEs performance in Pakistan: Moderating effects of knowledge intertia and external environment. South East Asia Journal of Contemporary Business, Economics and Law, 9(2).

Hassan, M. T., Burek, S., \& Asif, M. (2017). Barriers to Industrial Energy Efficiency ImprovementManufacturing SMEs of Pakistan. Energy Procedia, 113, 135-142.

Henseler, J., Ringle, C. M., \& Sarstedt, M. (2015). A new criterion for assessing discriminant validity in variance-based structural equation modeling. Journal of the Academy of Marketing Science, 43(1), 115-135.

Henseler, J., Ringle, C. M., \& Sinkovics, R. R. (2009). The use of partial least squares path modeling in international marketing New challenges to international marketing (pp. 277-319): Emerald Group Publishing Limited.

Hussain, J., Ismail, K., \& Akhtar, C. S. (2015). Market orientation and organizational performance: case of Pakistani SMEs. Arabian Journal of Business and Management Review, 5(5), 1-6.

Ibeh, K. I. (2004). Furthering export participation in less performing developing countries: The effects of entrepreneurial orientation and managerial capacity factors. International Journal of Social Economics, $31(1 / 2), 94-110$. 
Imran, M., binti Abdul Hamid, S. N., \& binti Aziz, A. (2017). Total quality management, export market orientation and firm export performance: A Conceptual Framework. International Journal of Academic Research in Business and Social Sciences, 7(9), 591-601.

Imran, M., binti Aziz, A., \& binti Abdul Hamid, S. N. (2016). Moderating role of environmental turbulence on the relationship between enterpreneural orientation, business networks orientation, export market orientation and SMEs export performance: A research framework. Journal of Business Management, Commerce \& Research,6(15).

Imran, M., binti Aziz, A., \& binti Abdul Hamid, S. N. (2017). The relationship between entrepreneurial orientation, business networks orientation, export market orientation and SME export performance: A proposed research framework. International Journal of Academic Research in Business and Social Sciences, $7(10), 230-248$.

İpek, İ. (2017). The resource-based view within the export context: An integrative review of empirical studies. Journal of Global Marketing, 1-23.

Jafari, H. (2013). Developing EFQM and VIKORE methods as appropriate framework for evaluating the performance of Iranian free trade zones. Applied mathematics in Engineering, Management and Technology, $1(4), 24-34$.

Javalgi, R. R. G., \& Todd, P. R. (2011). Entrepreneurial orientation, management commitment, and human capital: The internationalization of SMEs in India. Journal of Business Research, 64(9), 1004-1010.

Kanji, G. K. (1990). Total quality management: the second industrial revolution. Total quality management, 1(1), 3-12.

Khalique, M., Bontis, N., Abdul Nassir bin Shaari, J., \& Hassan Md. Isa, A. (2015). Intellectual capital in small and medium enterprises in Pakistan. Journal of Intellectual Capital, 16(1), 224-238.

Khan, M. W. J., \& Khalique, M. (2014). An Overview of Small and Medium Enterprises in Malaysia and Pakistan: Past, Present and Future Scenario. Business and Management Horizons, 2(2), 38.

Krejcie, R. V., \& Morgan, D. W. (1970). Determining sample size for research activities. Educational and Psychological Measurement, 30(3), 607-610.

Lages, L. F. (2000). A conceptual framework of the determinants of export performance: reorganizing key variables and shifting contingencies in export marketing. Journal of Global Marketing, 13(3), 29-51.

Lages, L. F., Silva, G., \& Styles, C. (2009). Relationship capabilities, quality, and innovation as determinants of export performance. Journal of International Marketing, 17(4), 47-70.

Latif, Y., Fiaz, M., \& Shoaib, M. (2014). Important TQM Implementation Contributors in Pakistani Petrochemical Sector. Pakistan Journal of Statistics and Operation Research, 10(3).

LCCI. (2017). Untapped Export Potentail of Pakistan. Retrieved from Lahore, Pakistan: http://www.lcci.com.pk/research-department/lccirnd/attachments/export\%20book-final.pdf

Lefebvre, E., Lefebvre, L. A., \& Bourgault, M. (1998). R\&D-related capabilities as determinants of export performance. Small Business Economics, 10(4), 365-377.

Majocchi, A., Bacchiocchi, E., \& Mayrhofer, U. (2005). Firm size, business experience and export intensity in SMEs: A longitudinal approach to complex relationships. International Business Review, 14(6), 719-738.

Masakure, O., Henson, S., \& Cranfield, J. (2009). Standards and export performance in developing countries: Evidence from Pakistan. The Journal of International Trade \& Economic Development, 18(3), 395-419.

Mostafa, R. H., Wheeler, C., \& Jones, M. V. (2005). Entrepreneurial orientation, commitment to the Internet and export performance in small and medium sized exporting firms. Journal of International Entrepreneurship, 3(4), 291-302.

Muller, P., Caliandro, C., Viktoriya , P., Gagliardi, D., Marzocchi, C., Ramlogan, R., \& Cox, D. (2015). European Comission: Annual Report on European SMEs 2014/2015. Retrieved from Berlin, Germany: http://ec.europa.eu/DocsRoom/documents/16341/attachments/2/translations/en/renditions/native

Munir, A. (2016). SMEs need technology upgrade. DAWN. Retrieved from http://www.dawn.com/news/1242458/smes-need-technology-upgrade

Nation, T. (2016). Ahsan stresses need for non-traditional SMEs promotion. The Nation. Retrieved from http://nation.com.pk/national/18-Oct-2016/ahsan-stresses-need-for-non-traditional-smes-promotion

Okpara, J. O., \& Kabongo, J. D. (2009). The entrepreneurial export orientation and performance of small firms in a developing economy. International Journal of Globalisation and Small Business, 3(3), 288-305.

Para-González, L., Jiménez-Jiménez, D., \& Martínez-Lorente, Á. n. R. (2016). Building human capital in the European Foundation for Quality Management model of excellence. International Journal of Human Resources Development and Management, 16(3-4), 219-237.

PBS. (2016). Export performance of Pakistan. Pakistan Bureau of Statistics Government of Pakistan Retrieved from http://www.pbs.gov.pk/. 
Rehman, N. U. (2016). Network alliances and firms' performance: a panel data analysis of Pakistani SMEs. Eurasian Business Review, 6(1), 37-52.

Ringle, C. M., Sarstedt, M., \& Straub, D. (2012). A critical look at the use of PLS-SEM in MIS Quarterly.

Saeed, \& Hasnu, S. (2011). Total quality management in exporting SME s of Pakistan: A case study of sports goods manufacturers at Sialkot. Interdisplinary Journal of Contemporary Research in Business, 2(12).

Salkind, N. J. (2012). Exploring Research: Pearson Education, Inc, New Jersey.

Saunders, M., Lewis, P., \& Thornhill, A. (2009). Research methods for business students (Vol. 5): Pearson Education Limited, Edinburgh.

Sekaran, U., \& Bougie, R. J. (2016). Research methods for business: A skill building approach (Vol. 7): John Wiley \& Sons.

Shafiq, M. (2012). Implementation of quality management systems and business excellence frameworks in Pakistani textile companies. Journal of Quality and Technology Management, 7(2), 11-23.

Shafiq, M., Lasrado, F., \& Hafeez, K. (2017). The effect of TQM on organisational performance: empirical evidence from the textile sector of a developing country using SEM. Total Quality Management \& Business Excellence, 1-22.

Shamsuddoha, A., Yunus Ali, M., \& Oly Ndubisi, N. (2009). Impact of government export assistance on internationalization of SMEs from developing nations. Journal of Enterprise Information Management, 22(4), 408-422.

Shoham, A., Brencic, M. M., Virant, V., \& Ruvio, A. (2008). International standardization of channel management and its behavioral and performance outcomes. Journal of International Marketing, 16(2), 120 151.

Sui, S., \& Baum, M. (2014). Internationalization strategy, firm resources and the survival of SMEs in the export market. Journal of International Business Studies, 45(7), 821-841.

Teece, D. J. (2007). Explicating dynamic capabilities: the nature and microfoundations of (sustainable) enterprise performance. Strategic Management Journal, 28(13), 1319-1350.

Teece, D. J., Pisano, G., \& Shuen, A. (1997). Dynamic capabilities and strategic management. Strategic Management Journal, 18(7), 509-533.

Teixeira, A. A., Jabbour, C. J. C., de Sousa Jabbour, A. B. L., Latan, H., \& de Oliveira, J. H. C. (2016). Green training and green supply chain management: evidence from Brazilian firms. Journal of Cleaner Production, $116,170-176$.

Ural, T. (2009). The effects of relationship quality on export performance: A classification of small and mediumsized Turkish exporting firms operating in single export-market ventures. European Journal of Marketing, $43(1 / 2), 139-168$.

Wilkinson, T., \& Brouthers, L. E. (2006). Trade promotion and SME export performance. International Business Review, 15(3), 233-252.

Winter, S. G. (2003). Understanding dynamic capabilities. Strategic Management Journal, 24(10), 991-995.

Yoshino, N., \& Wignaraja, G. (2015). SMEs Internationalization and

Finance in Asia. Retrieved from Tokyo: https://www.imf.org/external/np/seminars/eng/2015/jica2015/pdf/1B1.pdf

Zhang, M., Sarker, S., \& Sarker, S. (2008). Unpacking the effect of IT capability on the performance of exportfocused SMEs: a report from China. Information Systems Journal, 18(4), 357-380.

Zhou, L., Wu, W.-p., \& Luo, X. (2007). Internationalization and the performance of born-global SMEs: the mediating role of social networks. Journal of International Business Studies, 38(4), 673-690.

Zou, S., \& Stan, S. (1998). The determinants of export performance: a review of the empirical literature between 1987 and 1997. International Marketing Review, 15(5), 333-356.

Zou, S., Taylor, C. R., \& Osland, G. E. (1998). The EXPERF scale: a cross-national generalized export performance measure. Journal of international Marketing, 37-58.

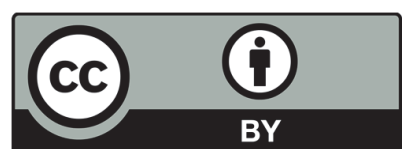

(C) 2018 by the authors; licensee Growing Science, Canada. This is an open access article distributed under the terms and conditions of the Creative Commons Attribution (CC-BY) license (http://creativecommons.org/licenses/by/4.0/). 